\title{
Hubungan Kekerapan Transfusi Darah dengan Kejadian Kolelitiasis dan Biliary Sludge pada Pasien Talassemia Mayor Anak
}

\section{Dandy Utama Jaya, Lelani Reniarti, Alex Chairulfatah}

Bagian Ilmu Kesehatan Anak Fakultas Kedokteran Universitas Padjadjaran/RS Dr. Hasan Sadikin Bandung

Latar belakang. Kolelitiasis (batu kandung empedu) merupakan penyakit kandung empedu yang dapat terjadi pada talassemia. Biliary sludge (pelumpuran kandung empedu) merupakan keadaan yang dapat menjadi kolelitiasis. Perubahan fungsi kandung empedu akibat penumpukan besi dan peningkatan kadar bilirubin serum akan mempermudah terjadinya kolelitiasis dan biliary sludge.

Tujuan. Mengetahui hubungan kekerapan transfusi darah dengan kejadian kolelitiasis dan biliary sludge pada talassemia mayor anak.

Metode. Penelitian menggunakan rancangan analitik cross-sectional. Subjek penelitian adalah pasien thalassemia mayor anak di Poliklinik Talassemia RS Hasan Sadikin Bandung berusia 5-14 tahun pada bulan Juni-Agustus 2010. Pada setiap subjek dilakukan anamnesis, pemeriksaan fisis, pemeriksaan kadar feritin dan bilirubin indirek serum serta pemeriksaan ultrasonografi hepatobilier. Analisis statistik menggunakan uji komparasi eksak Fisher, uji t tidak berpasangan dan uji Mann-Whitney.

Hasil. Sejumlah 60 subjek memenuhi kriteria penelitian. Kadar rata-rata feritin serum dan bilirubin indirek serum pada subjek yang mengalami kolelitiasis dan biliary sludge dibandingkan dengan yang tidak mengalami, tidak ditemukan perbedaan yang bermakna secara uji statistik ( 5682 vs 5113,$9 ; 1,19$ vs 1,$12 ; p>0,05)$. Didapatkan 6/60 subjek yang mengalami kolelitiasis dan biliary sludge, yaitu 3/60 subjek mengalami kolelitiasis, 2/60 subjek mengalami biliary sludge dan 1/60 subjek mengalami kolelitiasis dan biliary sludge Ditemukan perbedaan yang bermakna pada kejadian kolelitiasis dan biliary sludge antara pasien yang mendapat interval transfusi darah $\leq 3$ minggu dibandingkan dengan $>3$ minggu $(p<0,05)$.

Kesimpulan. Terdapat hubungan kekerapan transfusi darah dengan kejadian kolelitiasis dan biliary sludgepada talassemia mayor anak. Sari Pediatri 2010;12(4):217-21.

Kata kunci: biliary sludge, bilirubin serum, feritin serum, kolelitiasis, talassemia mayor

\begin{abstract}
Alamat korespondensi:
Dr. Dandy Utama Jaya, Bagian Ilmu Kesehatan Anak, Fakultas Kedokteran Universitas Padjadjaran/Rumah Sakit Dr. Hasan Sadikin Jl. Pasteur No. 38 Bandung 40163, Indonesia. Telepon. 022-2035957. E-mail:dandy.jaya@yahoo.com
\end{abstract}

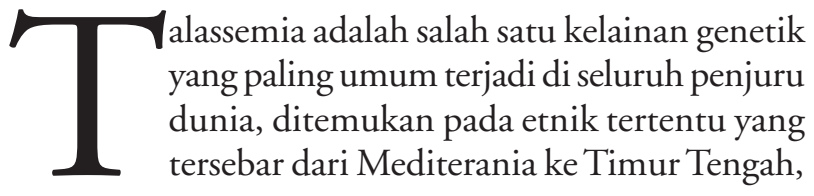


India, Birma, dan Asia Tenggara. Di Indonesia angka kejadian pembawa gen talassemia diperkirakan $3 \%-8 \% .^{1-3}$ Di Poliklinik Talassemia Subbagian Hematologi-Onkologi Bagian Ilmu Kesehatan Anak Fakultas Kedokteran Universitas Padjadjaran/Rumah Sakit Dr. Hasan Sadikin Bandung hingga akhir tahun 2009 tercatat 517 pasien talassemia.

Kolelitiasis merupakan salah satu penyakit kandung empedu semakin meningkat pada anak dalam tiga dekade terakhir, hasil pemeriksaan autopsi menemukan $0,1 \%-0,28 \%$ batu kandung empedu pada anak dengan sebab yang dikelompokkan menjadi kolelitiasis hemolitik dan nonhemolitik. Kolelitiasis hemolitik merupakan penyebab utama batu kandung empedu pada anak, terutama pada penyakit hemolitik kronik seperti sferositosis kongenital, anemia sicklecell, dan talassemia. Biliary sludge (pelumpuran pada kandung empedu) merupakan keadaan untuk terjadinya kolelitiasis. ${ }^{4-9}$

Sejak tahun 1990-an sejumlah penelitian telah dilakukan di Mesir, Iran, Thailand, dan Turki untuk mempelajari kejadian kolelitiasis dan biliary sludge pada kasus talassemia anak, terutama talassemia mayor dan intermedia. Insidens yang ditemukan bervariasi antara $8 \%$ sampai $18 \%$, yang semakin meningkat dengan bertambahnya usia. Di Indonesia, penelitian Nenny $\mathrm{dkk}^{10}$ di Yogyakarta menemukan hasil yang hampir serupa. Dari berbagai penelitian tersebut, kejadian kolelitiasis dan biliary sludge terutama disebabkan oleh perubahan fungsi kandung empedu akibat penumpukan besi pada usus halus proksimal dan kandung empedu ataupun karena peningkatan kadar bilirubin serum yang mempengaruhi pembentukan batu kandung empedu. ${ }^{11-14}$

Berdasarkan hasil penelitian tersebut, kami membuat hipotesis bahwa semakin berat hemolisis yang terjadi yang ditandai dengan interval transfusi darah yang semakin pendek akan menyebabkan peningkatan kadar bilirubin serum dan penumpukan zat besi menyebabkan kejadian kolelitiasis dan biliary sludge akan meningkat. Penelitian bertujuan mengetahui hubungan kekerapan transfusi darah dengan kejadian kolelitiasis dan biliary sludge pada pasien talassemia mayor anak.

\section{Metode}

Subjek penelitian adalah pasien talassemia mayor anak yang berobat ke Poliklinik Talassemia subbagian Hematologi-Onkologi Bagian/SMF Ilmu Kesehatan Anak Rumah Sakit Dr. Hasan Sadikin (RSHS) Bandung dan telah mendapat persetujuan tertulis dari orangtua/wali untuk ikut dalam penelitian setelah diberikan penjelasan (informed consent).

Kriteria inklusi adalah pasien talassemia mayor anak berusia 5-14 tahun yang berobat ke poliklinik talassemia dan memiliki catatan medis lengkap. Kriteria eksklusi apabila anak menderita penyakit infeksi, inflamasi, penyakit autoimun, obesitas, gagal jantung maupun keganasan.

Penelitian dilakukan pada bulan Juni-Agustus 2010, merupakan penelitian analitik observasional dengan rancangan studi cross-sectional. Metode pemilihan subjek dilakukan secara consecutive sampling, penentuan besar sampel menggunakan rumus untuk menguji dua rata-rata yang didapatkan 60 subjek. Seluruh subjek dicatat identitasnya, riwayat penyakit, dilakukan pemeriksaan fisis dan antropometri, kemudian dilakukan pengambilan sampel darah untuk pemeriksaan bilirubin indirek dan feritin serum. Selanjutnya seluruh subjek dilakukan pemeriksaan ultrasonografi (USG) hepatobilier oleh seorang ahli radiologi untuk melihat ada tidaknya kolelitiasis ataupun biliary sludge. Alat USG yang digunakan adalah merk GE Logic 260 Pro series dengan probe konveks 3-5 MHz.

Dilakukan uji komparasi eksak Fisher untuk mengetahui perbandingan/perbedaan variabel kategorik, serta uji komparasi berdasarkan uji t tidak berpasangan dan uji Mann-Whitney untuk mengetahui perbandingan/perbedaan variabel numerik. Kemaknaan ditentukan berdasarkan nilai $\mathrm{p}<0,05$. Seluruh perhitungan statistik dikerjakan dengan piranti lunak SPSS version 17.0 for Windows tahun 2007, SPSS inc., Chicago-Illinois, USA. Penelitian telah mendapat persetujuan Komite Etik Penelitian Kesehatan Fakultas Kedokteran Universitas Padjadjaran RS. Dr. Hasan Sadikin Bandung.

\section{Hasil}

Selama penelitian didapatkan 60 subjek yang memenuhi kriteria, subjek penelitian terdiri dari 35 laki-laki dan 25 perempuan. Pada karakteristik umum subjek tidak terdapat perbedaan bermakna di antara kedua kelompok (Tabel 1). 
Tabel 1. Karakteristik umum subjek penelitian

\begin{tabular}{|c|c|c|c|}
\hline \multirow[b]{2}{*}{ Variabel } & \multicolumn{2}{|c|}{ Kolelitiasis dan biliary sludge } & \multirow[b]{2}{*}{ Nilai $p$} \\
\hline & $\begin{array}{c}\text { Positif } \\
n=6\end{array}$ & $\begin{array}{c}\text { Negatif } \\
n=54\end{array}$ & \\
\hline \multicolumn{4}{|c|}{ Jenis kelamin, n (\%) } \\
\hline Laki-laki & $5(83,3)$ & $30(55,5)$ & $0,386^{*}$ \\
\hline Perempuan & $1(16,7)$ & $24(44,5)$ & \\
\hline \multicolumn{4}{|l|}{ Usia (tahun) } \\
\hline Median & 12 & 10 & $0,153^{* *}$ \\
\hline Rentang & $8-13$ & $5-14$ & \\
\hline \multicolumn{4}{|c|}{ Usia diagnosis (bulan) } \\
\hline Median & 16,5 & 9 & $0,523^{* *}$ \\
\hline Rentang & $4-108$ & $2-144$ & \\
\hline \multicolumn{4}{|c|}{ Usia menggunakan kelasi besi (tahun) } \\
\hline Median & 6 & 5 & $0,303^{* *}$ \\
\hline Rentang & $3-9$ & $1-11$ & \\
\hline \multicolumn{4}{|c|}{ Keluhan sugestif, n (\%) } \\
\hline Positif & 0 & $11(20,4)$ & $0,581^{*}$ \\
\hline Negatif & $6(100)$ & $43(79,6)$ & \\
\hline \multicolumn{4}{|c|}{ Status gizi, n (\%) } \\
\hline Gizi baik & $6(100)$ & $44(81,5)$ & $0,577^{*}$ \\
\hline Gizi kurang & 0 & $10(18,5)$ & \\
\hline
\end{tabular}

Keterangan: ${ }^{*}=$ nilai $p$ berdasarkan uji eksak Fisher ** = nilai $p$ berdasarkan uji Mann-Whitney

Tabel 2 memperlihatkan kadar rata-rata feritin serum dan bilirubin indirek serum pada subjek yang mengalami kolelitiasis dan biliary sludge, tidak ditemukan perbedaan yang bermakna secara uji statistik ( $p>0,05)$ pada kedua kelompok.

Pada Tabel 3 tampak kejadian kolelitiasis dan biliary sludge hanya ditemukan pada subjek dengan interval transfusi $\leq 3$ minggu sebanyak enam subjek, yaitu tiga subjek kolelitiasis, dua subjek biliary sludge dan satu subjek kolelitiasis dan biliary sludge, perbedaan tersebut berbeda bermakna berdasarkan uji statistik $(p<0,05)$.

Tabel 2. Hubungan kadar feritin dan bilirubin indirek serum dengan kejadian kolelitiasis dan biliary sludge

\begin{tabular}{lccc}
\hline \multirow{2}{*}{ Variabel } & \multicolumn{2}{c}{ Kolelitiasis dan biliary sludge } & \multirow{2}{*}{ Nilai $p$} \\
\cline { 2 - 3 } & $\begin{array}{c}\text { Positif } \\
\mathrm{n}=6\end{array}$ & $\begin{array}{c}\text { Negatif } \\
\mathrm{n}=54\end{array}$ & \\
\hline Kadar feritin serum (ng/dL) & 5682 & 5113,9 & 0,61 \\
$\quad$ Rerata & 2822,3 & 2735,9 & \\
Simpang baku & $1792-10007$ & $1319-13894$ & \\
Rentang & & & \\
Kadar bilirubin serum indirek (mg/dL) & 1,19 & 1,12 & 0,84 \\
$\quad$ Rerata & 0,7 & 0,76 & \\
Simpang baku & $0,25-2,46$ & $0,11-3,75$ & \\
Rentang & & & \\
\hline
\end{tabular}

Keterangan: nilai $p$ berdasarkan uji t 
Dandy Utama Jaya dkk: Hubungan kekerapan transfusi darah dengan kejadian kolelitiasis dan biliary sludge pada pasien talassemia mayor anak

Tabel 3. Hubungan kekerapan transfusi darah dengan kejadian kolelitiasis dan biliary sludge

\begin{tabular}{lccc}
\hline \multirow{2}{*}{ Variabel } & \multicolumn{2}{c}{ Kolelitiasis dan biliary sludge } & \multirow{2}{*}{ Nilai $p$} \\
\cline { 2 - 3 } & $\begin{array}{c}\text { Positif } \\
\mathrm{n}=6\end{array}$ & $\begin{array}{c}\text { Negatif } \\
\mathrm{n}=54\end{array}$ & \multirow{2}{*}{0,024} \\
$\begin{array}{l}\text { Interval transfusi darah, minggu } \mathrm{n}(\%) \\
\leq 3\end{array}$ & $6(100)$ & $24(44,5)$ & \\
$>3$ & 0 & $30(55,5)$ & \\
\hline
\end{tabular}

Keterangan: nilai $p$ berdasarkan uji Eksak-Fisher

\section{Pembahasan}

Hasil penelitian menemukan kejadian kolelitiasis dan biliary sludge sebanyak enam subjek, yaitu tiga subjek kolelitiasis, dua subjek biliary sludge, dan satu subjek kolelitiasis dan biliary sludge. Temuan tersebut lebih sedikit dibandingkan dengan laporan Lotfi $\mathrm{dkk}^{11} \mathrm{di}$ Iran dari 153 subjek (usia 9-21 tahun) ditemukan 15 subjek (10\%) mengalami kolelitiasis dan 20 subjek mengalami biliary sludge (13\%). Nasr $\mathrm{dkk}^{9}$ di Cairo Mesir mendapatkan $18 \%$ kolelitiasis dan $6,6 \%$ biliary sludge dari 61 subjek usia 2,5-18 tahun. Sedangkan Kalayci $\mathrm{dkk}^{14}$ menemukan 11,8\% kolelitiasis dan 29,4\% biliary sludge dari 17 subjek usia 7-17 tahun, dan Senaati dkk ${ }^{13}$ melaporkan 8,4\% kolelitiasis dari 83 subjek yang diteliti (usia 3-13 tahun). Insidensi kolelitiasis dan biliary sludge memang belum dapat ditentukan secara pasti dan masih didapatkan hasil yang beragam pada berbagai hasil penelitian, kemungkinan karena perbedaan besar sampel yang digunakan, usia subjek, interval transfusi, serta perbedaan heterogenitas genetik talassemia.

Kejadian kolelitiasis dan biliary sludge hanya ditemukan pada subjek dengan interval transfusi $\leq 3$ minggu, yang berbeda bermakna berdasarkan uji statistik $(p<0,05)$ (Tabel 3). Hasil tersebut sesuai dengan temuan Lotfi $\mathrm{dkk}^{11}$ yang menyimpulkan bahwa kejadian kolelitiasis semakin meningkat pada subjek dengan interval transfusi $\leq 3$ minggu (21 hari).

Kadar rata-rata feritin serum dan bilirubin indirek serum pada subjek yang mengalami kolelitiasis dan biliary sludge tidak berbeda dibandingkan dengan kelompok subjek yang tidak mengalami kolelitiasis dan biliary sludge $(p>0,05)$ (Tabel 2). Pada penelitianpenelitian sebelumnya didapatkan perbedaan di antara dua kelompok, kemungkinan karena terdapat perbedaan metode penelitian yang dipergunakan. Penelitian-penelitian tersebut membandingkan kelompok pasien talassemia dengan subjek sehat, sedangkan penelitian ini membandingkan kelompok pasien talassemia berdasarkan kejadian kolelitiasis dan biliary sludge.

Kelebihan penelitian ini adalah penelitian pertama di RS Hasan Sadikin yang membandingkan interval transfusi darah, kadar feritin serum, dan bilirubin indirek serum pada penderita thalassemia mayor anak yang mengalami kolelitiasis dan biliary sludge dibandingkan dengan yang tidak mengalaminya. Kelemahan penelitian adalah jumlah subjek yang mengalami kolelitiasis dan biliary sludge hanya sedikit sehingga diperlukan penelitian serupa dengan jumlah subjek yang lebih besar. Selain itu data mengenai jumlah darah transfusi dengan interval transfusi $\leq 3$ minggu dan $>3$ minggu tidak diperoleh karena ketidaklengkapan dokumentasi medik, sehingga tidak dapat diketahui apakah terdapat hubungan jumlah darah transfusi dengan kejadian kolelitiasis dan biliary sludge.

\section{Kesimpulan}

Terdapat hubungan kekerapan transfusi darah dengan kejadian kolelitiasis dan biliary sludge pada talassemia mayor anak. Untuk meningkatkan kualitas hidup pasien talassemia mayor anak, maka diperlukan skrining terhadap kejadian kolelitiasis ataupun biliary sludge walaupun belum dijadikan pedoman umum tata laksana, tetapi perlu mendapat perhatian karena kemungkinan terjadinya kedua hal tersebut. Hasil penelitian diharapkan dapat dijadikan acuan kewaspadaan untuk kemungkinan terjadinya kolelitiasis dan biliary sludge pada talassemia dengan interval transfusi darah sering.

\section{Daftar pustaka}

1. Weatheral DJ. The thalassemias. Dalam: Beutler E, Litchman M, Coller B, Kipps T, penyunting. Williams 
hematology. Edisi ke-6. New York: McGraw-Hill; 2001.h.547-80

2. Wahidayat I. Thalassemia dan permasalahannya di Indonesia. Kongres Nasional Ilmu Kesehatan Anak XI. Jakarta: 1999.

3. Benz EJ, Giardana PJ. Thalassemia syndrome. Dalam: Miller DR, Baechner RL, penyunting. Blood disease of infancy and childhood. Edisi ke-7. Baltimore: Mosby Inc; 1995.h.460-98.

4. Giardana PJ, Hilgartner MW. Update on thalassemia. Pediatr Rev. 1992;13:55-62.

5. Olivieri NF, Brittenham GM. Iron-chelating therapy and the treatment of thalassemia. J Am Society Hematol 1997;89:739-54.

6. Holcomb III GW, Andrews WS. Gallbladder disease and hepatic infections. Dalam: Grosfeld JL, O'Neill JA, Coran AG, Fonkalsrud EW, penyunting. Pediatric surgery. Edisi ke-6. Philadelphia: Mosby; 2006.h.163549.

7. Miyano T. Biliary tract disorder and portal hypertension. Dalam: Ashcraft KW, Holcomb III GW, Murphy JP, penyunting. Pediatric surgery. Edisi ke-4. Philadelphia: Elsevier Saunders; 2005.h.586-608.

8. Nio ROM. The jaundiced infant: biliary atresia and others obstructions. Dalam: O’Neill JA, Rowe MI, Grosfeld JL, Fonkalsrud EW, Coran AG, penyunting. Pediatric surgery. Edisi ke-5. Missouri: Mosby; 1998.h.1465-81.

9. Nasr MR, Shaker M, Mahdi H, Hafez A. Gall bladder contractility in children with beta-thalassaemia. Eastern Mediterranean Health J 2009;15:315-21.

10. Nenny SM, Sumadiono, Sustiyanto. Pigmented gallstone in children with thalassemia syndrome. Berkala Ilmu Kedokteran 2007;39:101-4.

11. Lofti M, Keramati P, Assadsangabi R, Nabavizadeh SA, Karimi M. Ultrasonographic Assessment of the prevalence of cholelithiasis and biliary sludge in $\beta$-thalassemia patients in Iran. Med Sci Monit 2009;15:398-402.

12. Chittmittrapap S, Buachum V, Dharmklong-at A. Cholelithiasis in thalassemic children. Pediatr Surg Int 1990;5:114-7.

13. Senaati A, Gumruk FU, Delbakhsh P, Balkanci F, Altay C. Gallbladder pathology in pediatric beta-thalassemic patients. Pediatr Radiol 1993;23:357-9.

14. Kalayci AG, Albayrak D, Gunes M, Incesu L, Agac $\mathrm{R}$. The incidence of galbladder stones and gallbladder function in beta-thalassemic children. Acta Radiologica 1999; 40:440-3. 